\title{
KETERSEDIAAN SARANA DAN PRASARANA BIMBINGAN DAN KONSELING DI SEKOLAH MENENGAH DI KABUPATEN GUNUNGKIDUL
}

\author{
Caraka Putra Bhakti \\ Bimbingan dan Konseling, Universitas Ahmad Dahlan \\ E-mail : caraka.pb@bk.uad.ac.id
}

\begin{abstract}
Abstrak
Tujuan penelitian adalah mendeskripsikan ketersediaan sarana dan prasarana bimbingan dan konseling di sekolah tingkat SMP,SMA,SMK baik negeri atau swasta. Salah satu keberhasilan layanan bimbingan dan konseling, ditunjang dengan fasilitas sarana dan prasarana yang memadai. Jenis penelitian ini adalah survei. Metode penelitian yang digunakan adalah mixed method. Instrumen penelitian adalah angket semi terbuka. Subjek penelitian sekolah menengah tingkat SMP, SMA, dan SMK di kabupaten gunungkidul yang berjumlah 17 sekolah. Teknik analisis data menggunakan statistik deskriptif dengan prosentase. Hasil penelitian menunjukkan : (1) seluruh sekolah telah miliki ruang kerja bimbingan dan konseling, (2) Ketersediaan ruang administrasi 10 sekolah memiliki sedangkan 7 sekolah belum memiliki, (3) ketersediaan ruang konseling individu 10 sekolah telah miliki, 7 sekolah belum memiliki, (4) ketersediaan ruang bimbingan dan konseling kelompok terdapat 8 sekolah telah memiliki, 9 sekolah belum memiliki, (5) seluruh sekolah belum memiliki ketersediaan ukuran minimal ruang bimbingann dan konseling, hasil penelitian rerata luas ruangan setiap sekolah $28,2 \mathrm{~m}^{2}$. Hambatan pengembangan sarana dan prasarana bimbingan dan konseling pada aspek pembiayaan dan lahan. Implikasi bagi guru bimbingan dan konseling di tuntut memiliki kreativitas dalam pelaksanaan layanan dengan fasilitas terbatas tanpa mengorbankan pelayanan optimal bagi pserta didik.
\end{abstract}

Kata Kunci: sarana, prasarana, bimbingan, konseling

\begin{abstract}
The purpose of research is to describe the availability of facilities and infrastructure of guidance and counseling in that exist in Junior High School, Senior High School, and Vocational High School both of public and private school. One of the successes of guidance and counseling, supported by facilities and infrastructure facilities. This type of research is a survey. The research method used is mixed method. The research instrument is semi-open questionnaire. The subjects of the research were secondary school in Junior High School, Senior High School, and Vocational High School in Gunungkidul district, which amounted to 17 schools. Subject secondary school studies junior high schools, high school and vocational school in the district Gunungkidul totaling 17 schools. Data analysis techniques use descriptive statistics with percentages. The results of the study show: (1) all schools have counseling and guidance room, (2) Availability of administration room, 10 schools already owned, while 7 schools yet, (3) availability of individual counseling room, 10 schools already owned, 7 schools yet (4) availability of guidance and counseling group room, 8 schools already owned, 9 schools yet, (5) the whole school has no minimum availability of guidance and counseling space, the result of the study of the average space of each school is $28.2 \mathrm{~m} 2$. Barriers to the development of facilities and infrastructure of guidance and counseling are on financing and land aspects. Implications for guidance and counseling teachers are required to have creativity in the implementation of services with limited facilities without sacrificing optimal services for students.
\end{abstract}

Keywords: infrastructure, facilities, guidance

\section{PENDAHULUAN}

Peraturan Menteri Pendidikan Nasional Republik Indonesia No 24 Tahun 2007 tentang Standar Sarana dan Prasarana untuk Sekolah Dasar/Madrasah Ibtidaiyah (SD/MI),
Menengah
Pertama/Madrasah Tsanawiyah (SMP/MTs), dan Sekolah Menengah Atas/Madrasah Aliyah (SMA/MA) menegaskan satuan pendidikan wajib memiliki sarana yang meliputi perabot, peralatan pendidikan, media pendidikan, buku dan sumber belajar lainnya, bahan habis pakai, serta perlengkapan 17 lain yang diperlukan 
untuk menunjang proses pembelajaran yang teratur dan berkelanjutan. Setiap satuan pendidikan wajib memiliki prasarana yang meliputi lahan, ruang kelas, ruang pimpinan satuan pendidikan, ruang pendidik, ruang tata usaha, ruang perpustakaan, ruang laboratorium, ruang bengkel kerja, ruang unit produksi, ruang kantin, instalasi daya dan jasa, tempat berolahraga, tempat beribadah, tempat bermain, tempat berkreasi, dan ruang/tempat lain yang diperlukan untuk menunjang proses pembelajaran yang teratur dan berkelanjutan.

Sejalan dengan kebijakan tersebut, ketersediaan prasarana sarana pendidikan salah satunya adalah ketersediaan prasaran dan sarana bimbingan dan konseling. Menurut (Hasan \& Bhakti 2016) layanan bimbingan dan konseling sebagai layanan profesional yang diselenggarakan pada satuan pendidikan meliputi komponen program, layanan lapangan, struktur dan Program layanan, kegiatan dan layanan alokasi waktu. Komponen program mencakup layanan dasar, spesialisasi layanan dan perencanaan individual, layanan responsif, dan sistem dukungan, sedangkan area layanan terdiri dari bidang pribadi, sosial, belajar, dan karir. Komponen bidang program dan layanan dituangkan ke dalam program tahunan dan semester dengan mempertimbangkan komposisi, proporsi dan waktu layanan alokasi, baik di dalam maupun di luar kelas. Sehingga keberhasilan layanan perlu ditunjang dengan fasilitas sarana dan prasarana yang memadai.

Namun, pada kenyataannya belum semua Guru Bimbingan dan Konseling melaksanakan berbagai macam program layanan bimbingan dan konseling yang telah disebutkan di atas secara optimal. Hal tersebut disebabkan belum terpenuhinya ruangan bimbingan dan konseling serta fasilitas pendukung lainnya yang mendukung terlaksananya program layanan bimbingan dan konseling. Padahal, ruangan bimbingan dan konseling serta fasilitas pendukung tersebut akan sangat membantu berjalannya layanan bimbingan dan konseling secara optimal. Seperti halnya yang disebutkan dalam (Kemendikbud 2014) tentang Bimbingan dan Konseling pada Pendidikan Dasar dan Pendidikan Menengah, yaitu "Penyelenggaraan layanan bimbingan dan konseling yang efektif dan efisien untuk mencapai tujuan layanan dan membantu tercapainya tujuan pendidikan nasional memerlukan sarana, prasarana, dan pembiayaan yang memadai."

Penelitian (Putranti 2015) menunjukkan baru $50 \%$ sekolah yang memiliki fasilitas sarana dan prasarana yang memadai sesuai dalam standar minimal ruang bimbingan dan konseling di Permendikbud No. 111 Tahun 2014. Menurut (Supriatna 2014):

"Fasilitas yang diharapkan tersedia di sekolah ialah ruangan tempat bimbingan dan konseling yang khusus dan teratur, serta perlengkapan lain yang memungkinkan tercapainya proses layanan bimbingan dan konseling yang bermutu".

Selanjutnya, (Suherman 2007) menegaskan untuk tercapainya program perencanaan BK yang efektif dan efisien, maka ada beberapa hal yang harus dilakukan yaitu: analisis kebutuhan siswa, penentuan tujuan BK, analisis situasi sekolah, penentuan jenis kegiatan yang akan dilaksanakan, penetapan metode pelaksanaan kegiatan, penetapan personel kegiatan, persiapan fasilitas dan biaya kegiatan, dan perkiraan tentang hambatan kegiatan dan antisipasinya. Amanat Permendikbud No 111 Tahun 2014 penyelenggaraan layanan bimbingan dan konseling yang efektif dan efisien untuk mencapai tujuan layanan dan membantu tercapainya tujuan pendidikan nasional memerlukan sarana, prasarana, dan pembiayanan yang memadai.

Menurut (Komalasari et al. 2011) pada kerangka kerja bimbingan dan konseling, asesmen sebagai dasar perancangan program bimbingan dan konseling yang sesuai dengan kebutuhan. Kegiatan Asesmen yang dilakukan pada dua area: (1) asesmen lingkungan, terkait dengan kegiatan mengindentifikasi harapan sekolah/Madrasah dan masyarakat (orangtua peserta didik), sarana prasarana pendukung program bimbingan, kondisi dan kualifikasi konselor, dan kebijakan pimpinan sekolah; dan (2) asesmen kebutuhan atau masalah peserta didik menyangkut karakteristik peserta didik, seperti aspek aspek-aspek fisik (kesehatan dan keberfungsiannya), kecerdasan, motif belajar, sikap dan kebiasaan belajar, minat-minatnya (pekerjaan, jurusan, olahraga, seni, dan keagamaan), masalah yang dialami, dan kepribadian atau tugas perkembangannya. Ketersediaan sarana dan prasarana bimbingan menjadi salah satu bagian kerangka kerja bimbingan dan konseling.

Menurut (Gysbers \& Henderson 2012) beberapa rekomendasi aktualisasi program untuk perubahan, pemimpin program bimbingan dan konseling perlu mempertimbangkan sumberdaya personil, sumber daya keuangan dan sumber daya politik program bimbingan dan konseling. Salah satu wujud sumber daya keuangan adalah ketersediaan fasilitas sarana dan prasarana yang memadai guna mendukung keterlaksanaan program bimbingan dan konseling yang optimal. Selanjutnya, menurut (Schmidt 2010) ketersediaan sarana dan prasarana konseling (counseling center) sangat mendukung keterlaksanaan aktivitas rutin layanan konseling di sekolah. ketersediaan sarana prasarana bimbingan dan konseling dipengaruhi oleh dukungan sistem sekolah terdapat bimbingan dan konseling. Dukungan sistem meliputi kebijakan-kebijakan terkait bimbingan dan konseling termasuk didalamnya penyediaan fasilitas yang memadai. Penelitian (Luddin 2013) menunjukkan kepala sekolah memiliki peran strategis dalam mencapai kegiatan bimbingan dan konseling efektif seperti penyediaan saran dan prasarana yang memadai.

Berdasarkan kajian diatas menunjukkan bahwa ketersediaan sarana bimbingan dan konseling menunjang keberhasilan layanan bimbingan dan konseling. Sehingga dirasa penting melakukan survei ketersediaan sarana dan prasarana bimbingan dan konseling di sekolah khususnya di kabupaten Gunungkidul. Berdasarkan paparan diatas, ketersediaan sarana prasarana bimbingan dan konseling sangat mendukung efektifitas layanana bimbingan dan konseling, maka bagaimana ketersediaan sarana dan 
prasarana bimbingan dan konseling di sekolah tingkat SMP,SMA,SMK ?

\section{METODE}

Penelitian ini merupakan mixed method dengan jenis penelitian survei. Waktu Penelitiian dimulai September-November 2016. Tempat penelitian adalah 17 (tujuh belas) sekolah tingkat SMP, SMA, SMK baik negeri atau swasta di kabupaten Gunungkidul. Instrumen yang digunakan adalah angket semi terbuka. Angket model ini dipilih karena memudahkan guru bimbingan konseling memberikan jawabaan. Dilihat dari cara pengisian angket menggunakan metode checklist. Instrumen ini dikembangkan berdasarkan sarana dan prasarana minimal sesuai dengan (Kemendikbud 2014) tentang Bimbingan dan konseling di Sekolah Dasar dan Sekolah Menengah, antara lain: 1) ruang bimbingan konseling (terdiri dari: ruang kerja sekaligus ruang konseling individual, ruangtamu, ruang bimbingan dan konseling, kelompok, ruang data, ruang konseling pustaka, dan ruang lainnya sesuai dengan perkembangan profesi bimbingan dan konseling); 2) fasilitas penunjang (dokumen program bimbingan dan konseling, instrumen pengumpul data).

Analisis data dalam penelitian ini adalah dengan menggunakan statistik deskriptif dengan teknik persentase, yaitu statistik yang berfungsi untuk mendeskrepsikan atau memberi gambaran terhadap obyek yang diteliti melalui sampel atau populasi sebagaimana adanya. Teknik persentase dalam analisis data dengan menggunakan kategori memiliki dan belum memiliki.

\section{HASIL DAN PEMBAHASAN}

a. Ruang Kerja Bimbingan dan Konseling Hasil penelitian menunjukan bahwa seluruh sekolah subyek penelitian memiliki ruang kerja bimbingan dan konseling

b. Ruang Administrasi

Ruang adminstrasi berfungsi untuk menyimpan data penting siswa. Hasil penelitian menunjukkan bahwa 10 sekoleh memiliki ruang data dan 7 sekolah belum tersedia ruang khusus ruang administrasi

c. Ruang Konseling Individu

Salah satu kompetensi konseliu adalah melaksanakan layanan konseling individu. Menurut (Kemendikbud 2016) konseling individual merupakan proses interaktif yang dicirikan oleh hubungan yang unik antara guru bimbingan dan konseling atau konselor dan peserta didik/konseli yang mengarah pada perubahan perilaku, konstruksi pribadi, kemampuan mengatasi situasi hidup dan keterampilan membuat keputusan. Konseling individual diberikan baik kepada peserta didik/konseli yang datang sendiri atau diundang. Peserta didik/konseli diundang oleh guru bimbingan dan konseling atau konselor berdasarkan hasil asesmen, referal, dan observasi.
Ketersediaan ruang konseling berfungsi melaksanakan layanan konseling individu secara nyaman dan rahasia. Hasil penelitian menunjukkan bahwa 10 sekolah telah memiliki ruang konseling indivdu dan 7 sekolah belum tersedia ruang khusus untuk konseling individu.

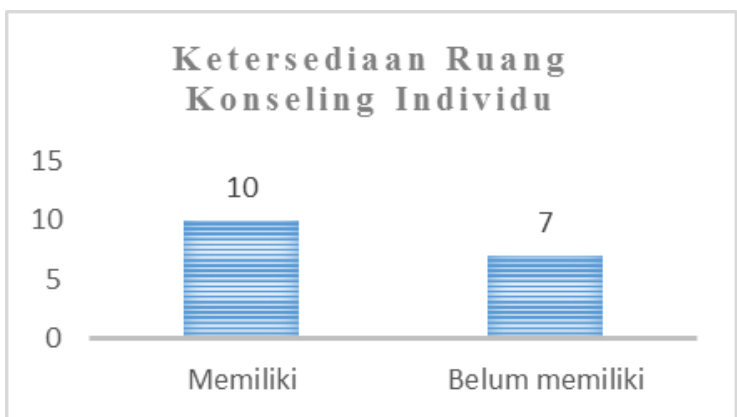

Gambar1. Ketersediaan ruang konseling individu

Ruang konseling perorangan (ruang konsultasi), berfungsi sebagai tempat untuk mengadakan wawancara konseling atau pertemuan perorangan.

Ruangan ini hendaknya dilengkapi dengan meja rendah atau semacam rak khusus untuk menaruh buku-buku, tas, dan map pengunjung serta filling cabinet untuk menyimpan data-data siswa.

d. Ruang Bimbingan dan Konseling Kelompok

Ruang bimbingan dan konseling kelompok berfungsi untuk melaksanakan layanan bimbingan kelompok, konseling kelompok serta layanan layanan yang dalam format kelompok. Hasil penelitian menunjukkan bahwa 8 sekolah memiliki ruang bimbingan dan konseling kelompok dan 9 sekolah belum tersedia ruang khusus untuk bimbingan dan konseling kelompok.

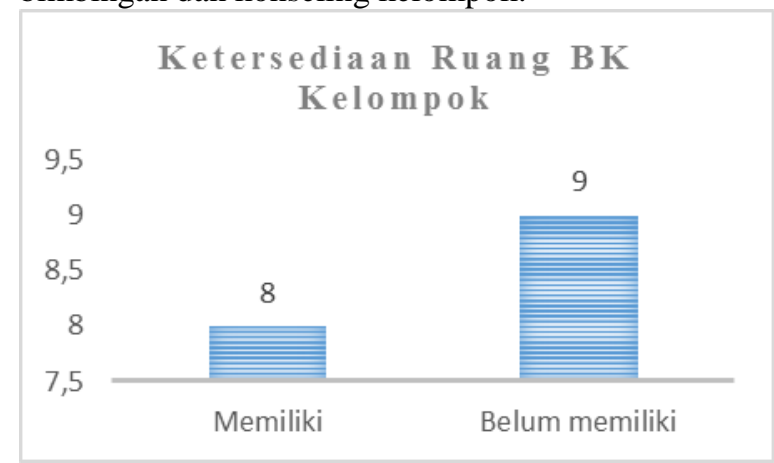

Gambar1. Ketersediaan ruang BK kelompok

Ruang bimbingan dan konseling kelompok, yang berfungsi sebagai tempat diskusi. Ruangan ini hendaknya dilengkapi dengan meja, kursi, whiteboard dan alat-alat lainnya sesuai dengan kebutuhan.

e. Fasilitas Penunjang

Fasilitas penunjang (Kemendikbud 2014) yang menyebutkan: "Selain ruangan, fasilitas lain yang diperlukan untuk penyelenggaraan bimbingan dan konseling antara lain: a) Dokumen program bimbingan dan konseling (buku program tahunan, 
buku semesteran, buku kasus, dan buku harian). b)Instrument pengumpul data dan kelengkapan administrasi seperti :

(1) Alat pengumpul data berupa tes.

(2) Alat pengumpul data teknik non-tes.

(3) Alat penyimpan data.

(4) Kelengkapan penunjang teknis.“

Hasil penelitian menunjukaan selurh sekolah telah memiliki dokumen progran tahunan dan semester, buku kasus dan buku harian.

Sedangkan ketersediaan instrumen pengumpulan data, berupa Angket Daftar Cek Masalah (DCM, Inventori Tugas Perkembangan (ITP), IKMS serta instrumen lain seperi angket kebutuhan yang dikembangkan guru bimbingan dan konseling.

f. Ukuran Ruangan bimbingan dan konseling

Berdasarkan (Kemendikbud 2014), salah contoh ukuran minimal ruang bimbingan dan konseling yang ideal, berukuran $8 \times 8$ yaitu seluas 64 meter persegi. Hasil penelitian menunjukkan bahwa secara keseluruhan sekolah belum memiliki ukuran yang ideal. Hasil penelitian rerata luas ruangan setiap sekolah 28,2 $\mathrm{m}^{2}$. Data lebih lengkap tersaji dibawah ini.

Tabel 1. Luas ruang bimbingan dan konseling setiap sekolah

\begin{tabular}{llc}
\hline No & Identitas Sekolah & Luas $\left(\right.$ dalam $\left.\mathrm{m}^{2}\right)$ \\
\hline 1 & Sekolah 1 & 9 \\
2 & Sekolah 2 & 18 \\
3 & Sekolah 3 & 48 \\
4 & Sekolah 4 & 45 \\
5 & Sekolah 5 & 18 \\
6 & Sekolah 6 & 25 \\
7 & Sekolah 7 & 45 \\
8 & Sekolah 8 & 16 \\
9 & Sekolah 9 & 20 \\
10 & Sekolah 10 & 30 \\
11 & Sekolah 11 & 36 \\
12 & Sekolah 12 & 28 \\
13 & Sekolah 13 & 25 \\
14 & Sekolah 14 & 48 \\
15 & Sekolah 15 & 36 \\
16 & Sekolah 16 & 16 \\
17 & Sekolah 17 & 16 \\
\hline Rerata Luas & 28,2 \\
\hline
\end{tabular}

g. Hambatan Ketersediaan sarana dan prasarana bimbingan dan konseling

Hasil penelitian menunjukkan ada dua alasan yang cukup kuat yang menghambat ketersediaan sarana dan prasarana bimbingandan konseling yaitu faktor biaya dan keterbatasan lahan. Pengembangan sarana bimbingan dan konseling melalui beberapa sumber dana. Menurut (Kemendikbud 2014) sumber biaya selain dari RKAS (Rencana Kegiatan dan Anggaran
Sekolah/Madrasah), dengan dukungan kebijakan Kepala Sekolah/Madrasah jika memungkinkan dapat mengakses dana dari sumber-sumber lain melalui kesepakatan lembaga dengan pihak lain, atau menggunakan sumber yang dialokasikan oleh komite Sekolah/Madrasah.

Dana pengembangan sarana dan prasarana bimbingan dan konseling sangat terbatas karena dana operasional sekolah banyak penunjang untuk aktivitas program rutin sekolah.

Kedua, keterbatasan lahan menjadi beberapa masalah penting, beberapa sekolah ruang bimbingan dan konseling sering berpindah karena menjadi ruang kelas bagi perkembangan jumlah peserta didik.

h. Implikasi bagi Guru Bimbingan dan Konseling

Guru bimbingan dan konseling adalah tenaga profesional, sehingga di tuntut melaksanakan layanan bimbingan dan konseling secara optimal. Keterbatasan sarana dan prasarana tidak mengurangi keterlaksanaan layanan bimbingan dan konseling. Guru bimbingan dan konseling dituntut kreatif dalam menyelenggarakan layanan bimbingan dan konseling, Salah satunya dapat menggunakan serambi masjid/mushola untuk konseling individu, konseling kelompok dan bimbingan kelompok.

\section{PENUTUP}

\section{Simpulan}

Keberhasilan keterlaksanaan layanan bimbingan dan konseling didukung oleh ketersediaan sarana dan prasarana bimbingan dan konseling yang memadai. Hasil penelitian menunjukkan seluruh sekolah telah memiliki ruang kerja bimbingan dan konseling, Namun, belum semua sekolah memiliki ruang administrasi, ruang konseling individu, dan ruang bimbingan dan konseling kelompok.

Hambatan pengembangan sarana dan prasarana bimbingan dan konseling pada aspek pembiayaan dan lahan. Implikasi bagi guru bimbingan dan konseling di tuntut memiliki kreativitas dalam pelaksanaan layanan dengan fasilitas terbatas tanpa mengorbankan pelayanan optimal bagi pserta didik. Namun demikian dalam borang akreditasi sekolah menyebutkan bahwa ketersediaan ruangan bimbingan dan konseling minimal $9 \mathrm{~m}^{2}$. Sehingga banyak sekolah berfokus memenuhi standar minimal sesuai standar akreditasi sekolah.

\section{Saran}

Keberhasilan layanan bimbingan dan konseling perlu ditunjang ketersediaan sarana dan prasarana bimbingan dan konseling yang memadai. Hasil penelitian menunjukkan belum terpenuhi ketersediaan secara minimal sarana dan prasarana layanan bimbingan dan konseling. Keterbatasan fasiltais tida mengurangi keterlaksanaaan layanan bimbingan dan konseling, dapat 
memanfaatkan e-konseling dalam melayani siswa serta

kreatif dalam merancang strategi layanan yang efektif.

\section{DAFTAR PUSTAKA}

Gysbers, N.C. \& Henderson, P., 2012. Developing and Managing Your School Guidance and Counseling Program Fifth Edition, Alexandria: American Counseling Assosiation.

Hasan, S.U.N. \& Bhakti, C.P., 2016. Guidance and Counselling: A Comparison between Indonesia and Malaysia. Scientific Journal of PPI-UKM, 3(6), pp.267-271.

Kemendikbud, 2014. Lampiran Permendikbud Nomor 111 Tahun 2014 Bimbingan dan Konseling pada Pendidikan Dasar dan Menengah, Indonesia.

Kemendikbud, 2016. Panduan Operasional Penyelenggaraan Bimbingan dan Konseling Sekolah Menengah Pertama (SMP), Jakarta: Kemendikbud RI.

Komalasari, G., Wahyuni, E. \& Karsih, 2011. Asesmen Teknik Nontes dalam Perspektif BK Komprehensif, Jakarta: PT. Indeks.

Luddin, A.B.M., 2013. Kinerja Kepala Sekolah dalam Kegiatan Bimbingan dan Konseling. Jurnal Ilmu Pendidikan, 19(2).

Putranti, D., 2015. Studi Deskriptif tentang Sarana dan Prasarana Bimbingan dan Konseling di Sekolah Menengah Pertama. PSIKOPEDAGOGIA Jurnal Bimbingan dan Konseling, 4(1), pp.45-50.

Schmidt, J.J., 2010. The elementary/Middle School Counselor Survival Guide Third Edition, Boston: John Wiley \& Sons.

Suherman, U., 2007. Manajemen Bimbingan Konseling, Bandung: Rizqi Press.

Supriatna, M., 2014. Bimbingan dan Konseling Berbasis Kompetensi Orientasi Dasar Pengembangan Profesi Konselor (Edisi Revisi), Jakarta: Raja Grafindo Persada. 